\title{
Prevalence of elimination stomas in a microregion in the north of Minas Gerais
}

\section{Prevalência de estomias de eliminação em uma microrregião do norte de Minas Gerais \\ Prevalencia de ostomías de eliminación en una micro-región del norte de Minas Gerais} Elisangela Ribeiro Barros ${ }^{1}$, Eline Lima Borges ${ }^{1}$, Célia Maria de Oliveira ${ }^{1}$

ORCID IDS

Barros ER (D) https://orcid.org/0000-0001-7590-7019

Borges EL (iD https://orcid.org/0000-0002-0623-5308

Oliveira CM (iD https://orcid.org/0000-0002-1937-7364

\section{HOW TO CITE}

Barros ER; Borges EL; Oliveira CM. Prevalence of elimination stomas in a microregion in the north of Minas Gerais. ESTIMA, Braz. J. Enterostomal Ther., 16:e3418. https://doi.org/10.30886/estima. v16.654 IN

\begin{abstract}
Objectives: To estimate the prevalence of people with elimination stoma and to characterize them for sociodemographic and clinical aspects. Method: A descriptive cross-sectional study with a sample of 27 patients with elimination stomas residing in a microregion in the north of Minas Gerais, who met the inclusion criteria. The data collected were recorded in an instrument used in previous studies and analyzed using descriptive statistics. Study approved by the Ethics Committee. Results: The prevalence of people with stoma was 2.16/10.000, the sample contained 55.6\% of men, $40.7 \%$ were married, mean age 59.1 years, $59.2 \%$ were literate and $74.0 \%$ had low income; $59.3 \%$ of the stomas were cancerous, more frequent colon and rectum tumours, $70.4 \%$ of the stomas were definitive, and $74.0 \%$ were colostomies. Dermatitis was the main complication and $68.2 \%$ of the patients presented effluent of pasty consistency and performed self-care. Conclusion: The prevalence of people with stoma was like that of other municipalities in Minas Gerais and below that expected by the National and International Ostomized Associations. The characterization of the people, of the stomas and the management of these, will contribute for health professionals and managers to review the assistance protocols used in the studied microregion.
\end{abstract}

DESCRIPTORS: Stoma; Surgical stomas; Nursing care; Health profile; Stomatherapy.

1 Universidade Federal de Minas Gerais - Escola de Enfermagem - Departamento de Enfermagem Básica - Belo Horizonte/MG - Brazil. Correspondence author: Eline Lima Borges | Av. Professor Alfredo Balena, 190 - Santa Efigênia | ZIP Code: 30.130-100 - Belo Horizonte/ MG - Brazil | E-mail: eborges@ufmg.br

Received: Oct 122018 | Accepted: Dec 182018 


\title{
RESUMO
}

Objetivos: Estimar a prevalência de pessoas com estomia de eliminação e caracterizá-las quanto aos aspectos sociodemográficos e clínicos. Método: Estudo transversal descritivo com amostra de 27 pacientes com estomias de eliminação, residentes em uma microrregião do norte de Minas Gerais, que atenderam aos critérios de inclusão. Os dados coletados foram registrados em instrumento utilizado em estudos anteriores e analisados por meio de estatística descritiva. Estudo aprovado pelo Comitê de Ética. Resultados: A prevalência de pessoas com estomia foi de 2,16/10.000, a amostra continha 55,6\% de homens, 40,7\% eram casados, com média de idade de 59,1 anos, 59,2,\% eram alfabetizados e 74,0\% tinham baixa renda; 59,3\% das estomias decorreram de câncer, sendo mais frequentes os de cólon e reto, 70,4\% das estomias eram definitivas e 74,0\% eram colostomias. Dermatite foi a principal complicação e $68,2 \%$ dos pacientes apresentavam efluente de consistência pastosa e realizavam autocuidado. Conclusão: A prevalência de pessoas com estomia foi semelhante à de outros municípios de Minas Gerais e abaixo do esperado pelas Associações Nacional e Internacional de Ostomizados. A caracterização das pessoas, das estomias e do manejo destas contribuirá para que profissionais de saúde e gestores revisem os protocolos de assistência utilizados na microrregião estudada.

DESCRITORES: Estomia; Estomas cirúrgicos; Cuidados de enfermagem; Perfil de saúde; Estomaterapia.

\begin{abstract}
RESUMEN
Objetivos: Estimar la prevalencia de personas con ostomía de eliminación y caracterizarlas con respecto a los aspectos sociodemográficos y clínicos. Método: Estudio transversal descriptivo con muestra de 27 pacientes con ostomías de eliminación, residentes en una micro-región del norte de Minas Gerais, que cumplieron los criterios de inclusión. Los datos recolectados fueron registrados en instrumento utilizado en estudios anteriores y analizados por medio de estadística descriptiva. Estudio aprobado por el Comité de Ética. Resultados: La prevalencia de personas con ostomía fue de 2,16/10.000, la muestra contenía 55,6\% de hombres, 40,7\% eran casados, con promedio de edad de 59,1 años, 59,2,\% eran alfabetizados y 74,0\% tenían baja renta; 59,3\% de las ostomías se derivaron de cáncer, siendo más frecuentes los de colon y recto, 70,4\% de las ostomías eran definitivas y 74,0\% eran colostomías. La dermatitis fue la principal complicación y $68,2 \%$ de los pacientes presentaban efluente de consistencia pastosa y realizaban auto-cuidado. Conclusión: La prevalencia de personas con ostomía fue semejante a la de otros municipios de Minas Gerais y por debajo de lo esperado por las Asociaciones Nacional e Internacional de Ostomizados. La caracterización de las personas, de las ostomías y del manejo de estas contribuirá para que los profesionales de la salud y los gestores revisen los protocolos de asistencia utilizados en la micro-región estudiada.
\end{abstract}

DESCRIPTORES: Ostomía; Estomas quirúrgicos; Cuidados de enfermería; Perfil de salud; Estomaterapia..

\section{INTRODUCTION}

The term stoma or ostomy derives from the Greek stoma and means opening. The stoma results from a surgical intervention to establish communication between a viscera and the external environment, either temporarily or permanently, to compensate for the functioning impaired by some disease or trauma. A stoma that has the function of elimination is denominated according to the externalized part: ileostomy, colostomy and urostomy ${ }^{1}$.

The presence of the stoma triggers significant changes in the life of the individuals, among them, the alteration of the body image. Adaptation to this new image occurs according to the emotional, cultural and previous experiences of each individual ${ }^{2}$. In this sense, social inclusion and rehabilitation of people with stoma become primary tasks for health professionals and, specifically, for nurses.
In Brazil, care for patients with a stoma is performed by the Service of Attention of Health of Ostomized People (SAHOP). This service is classified according to the complexity of the care provided and aims at the integral, specialized and interdisciplinary care to the person with the stoma. In the SAHOP, patients with stoma are enrolled in the Network of Care for Individuals with Disabilities of the Unified Health System (UHS) and acquire, monthly, the devices and adjuvants necessary for the care of the stoma. This service, in Minas Gerais, through the State Department, in addition to providing collecting equipment and adjuvants, must realize actions, through a multidisciplinary team, to provide guidance for self-care and prevention of complications related to the stomas ${ }^{3}$.

In the north of Minas Gerais (Brazil), study site, inequalities related to health needs are like those found 
in the northeast region and the Vale do Jequitinhonha. These regions present health needs above the general average observed in the state, comprising $14.0 \%$ of the state population ${ }^{4}$.

To supply part of these health-related demands, the health team of this microregion has sought to improve care for patients with stoma in SAHOP I, leveraging efforts to increase human resources in sufficient numbers to provide specialized multidisciplinary care to these people and adapt the physical structure to the criteria recommended by the Ordinance SAS/MS no 400, dated 11/16/2009. Through this initiative, the objective is to reduce the fragility of health actions aimed at rehabilitation, orientation for self-care, treatment and prevention of complications related to the stoma.

In this context, the lack of studies on the prevalence and characterization of people with stoma of this microregion is a factor that impairs the planning and actions directed at this clientele. It is worth mentioning that, despite the efforts to meet the needs of the users of this microregion, it is necessary to build a new assistance model focused on self-care.

\section{OBJECTIVES}

Considering that the patient's lack of information about the stoma can compromise self-care and that the non-characterization of the person with stoma constitutes an obstacle to the planning of actions and the management of health services, the objective of the study was to estimate the prevalence of people with elimination stoma and to characterize them regarding socio-demographic and clinical aspects in this microregion of Minas Gerais.

\section{METHOD}

This is descriptive, cross-sectional research involving people with elimination stoma and aiming at the prevalence of this disease in a microregion in the north of Minas Gerais.

The study was realized in the SAHOP I of Pirapora and involved the following municipalities of the north of Minas Gerais: Buritizeiro, Varzea da Palma, Ponto Chique,
Ibiai, Lassance and Santa Fe de Minas. The microregion comprises about $17.580 .000 \mathrm{~km}^{2}$ of territorial extension and an estimated population of 138.356 inhabitants. The municipalities have different distances from Pirapora, Buritizeiro being the nearest one, located at $8.1 \mathrm{~km}$, and Ponto Chique the furthest away ${ }^{5}$, at $120.9 \mathrm{~km}^{2}$.

The SAHOP I is in the host municipality and is a reference service, covering the entire microregion in the north of Minas Gerais. Only the municipalities of Santa Fe de Minas and Lassance do not yet have patients with stoma enrolled in this service.

The study lasted from January 2008 to November 2017 , corresponding to the period of service to this clientele, through a referral service that provides coverage to the microregion in the north of Minas Gerais.

To participate in the study, the patient should have intestinal and/or urinary elimination stoma, have a registry at the State Department of Health, be included in SAHOP I and sign the term of Free and Informed Consent.

The identification of the participant took place through the card in the service and it was contacted by telephone. In this process, it was verified that there were 45 patients with elimination stoma, and there were no patients from the municipalities of Santa Fe de Minas and Lassance. Of this total, nine had died; eight had submitted bowel reconstruction surgery and four had moved to another region. In addition, three patients were out of town for an indefinite period, and six were registered after the stoma was made during the study period. Thus, 27 people accepted to participate in the study, constituting the sample of this study.

Data collection occurred in December 2017 and was realized by one of the researchers. This consisted of interviewing and physical evaluation of the participant, including the stoma, the surrounding skin, and the collector device in use. Data on socioeconomic and demographic, behavioural and clinical variables were collected and recorded in a form that has already been used in previous studies conducted by this group of researchers. After this step, the data were entered into a database organized in the Microsoft Office Excel® program, version 2013, and analyzed using the descriptive statistics method.

In the calculation of the prevalence of people with intestinal and urinary elimination stoma in the 
microregion under study, in the period from 2008 to 2017, the number of users registered in the SAHOP was considered. The number of patients with a stoma in this service was calculated and divided by the number of inhabitants of the cities in the microregion surveyed.

The study was realized with the approval of the Research Ethics Committee, number 2.277.649, and the consent of the Municipal Secretary of Health of Pirapora, Minas Gerais. The ethical precepts established in Resolution 466 of 12th of December 2012 were respected. Participants signed the Informed Consent Term, with the guarantee of being aware of the research, the time to be made available for interview and clinical evaluation, as well as the dissemination and use of the data for scientific purposes.

\section{RESULTS}

The study sample consisted of 27 people with elimination stoma residing in a microregion in the north of Minas Gerais. The prevalence was 2.16/10.000 people in this region. The socioeconomic and demographic variables (Table 1) and clinical variables (Table 2) of the sample are presented below.

Most of the study participants reported residing at home with basic sanitation (81.5\%). Concerning cigarette use, $85 \%$ of the participants denied smoking and $15 \%$ reported smoking 3 to 4 cigarettes per day. The colostomy was the most prevalent of the types of the stoma (74.0\%), most of which were in the lower left quadrant (45.0\%), in a definitive way (65.0\%) and were terminal mouth (45.0\%). There was a predominance of low profile stoma with protrusion up to $1.5 \mathrm{~cm}(55.5 \%)$.

The patients presented effluent of liquid consistency (27.3\%), semipasteous (4.6\%) or pasty (68.2\%), with a pattern of elimination from several times a day (41\%) to once a day $(4,0 \%), 2(15 \%), 3(26.0 \%)$ and 4 to 5 (15\%) times daily. They reported elimination of flatus (82.0\%) with unpleasant odor (52.0\%).

Among the diseases that triggered the creation of the stoma, the neoplasia presented predominance (59.3\%), and the neoplasia of the rectum was the most prominent (43.75\%). The remaining neoplasias were in the sigmoid (18.75\%), uterus (6.25\%), cervix $(6.25 \%)$, ovary $(6.25 \%)$, bladder (12.5\%) and prostate $(6.25 \%)$.
The majority (66.7\%) of the patients presented complications related to the stoma due to incorrect use of the device and other clinical variables, such as body mass index. Dermatitis was the main complication found in the stoma (47.6\%) and in the peristomal skin (90.9\%), being related to incorrect use of the device, such as excessive cutting of the orifice of the protective barrier with exposure of the skin around the stoma to the action of the effluent. A paraestomal hernia was the second most common complication (18.5\%). The data showed that the largest proportion of people with a stoma $(85.2 \%)$ had the physical capacity to perform the care of the stoma and the device. However, only $48.0 \%$ of the patients performed the change of the device and $52.0 \%$ did the hygienization of the stoma.

Table 1. Socioeconomic and demographic aspects $(n=27)$ of the patients with stoma of a microregion in the north of Minas Gerais, Brazil.

\begin{tabular}{|c|c|c|c|}
\hline Variables & Categories & n (\%) & Mean \\
\hline \multirow{2}{*}{ Gender } & Female & $12(44.4)$ & - \\
\hline & Male & $15(55.6)$ & - \\
\hline \multirow{3}{*}{ Age (years) } & $<1$ & $1(3.7)$ & \multirow{3}{*}{59.1} \\
\hline & $43-59$ & $17(63.0)$ & \\
\hline & $67-82$ & $9(33.3)$ & \\
\hline \multirow{5}{*}{$\begin{array}{l}\text { Schooling } \\
\text { (years of study) }\end{array}$} & 0 & $8(29.6)$ & \multirow{5}{*}{4.4} \\
\hline & 1 to 4 & $9(33.3)$ & \\
\hline & 5 to 8 & $3(11.1)$ & \\
\hline & 9 to 12 & $6(22.2)$ & \\
\hline & 13 to 17 & $1(3.7)$ & \\
\hline \multirow{2}{*}{ Literacy } & Illiterate & $11(40.8)$ & - \\
\hline & Literate & $16(59.2)$ & - \\
\hline \multirow{6}{*}{ Marital status } & Married & $11(40.7)$ & - \\
\hline & Stable union & $1(3.7)$ & - \\
\hline & Single & $9(33.3)$ & - \\
\hline & Divorced & $3(11.1)$ & - \\
\hline & Widowed & $2(7.4)$ & - \\
\hline & Separated & $1(3.7)$ & - \\
\hline \multirow{3}{*}{ Color/Race } & White & $7(25.9)$ & - \\
\hline & Black & $6(22.2)$ & - \\
\hline & Brown & $14(51.9)$ & - \\
\hline Monthly family income & $<1 \mathrm{MW}$ & $1(3.7)$ & \multirow{3}{*}{1.7} \\
\hline (minimum wage [MW] & 1 a $2 \mathrm{MW}$ & $19(70.3)$ & \\
\hline $\mathrm{R} \$ 937.00)$ & 2 a $3 \mathrm{MW}$ & $7(25.9)$ & \\
\hline \multirow{2}{*}{ Retired } & Yes & $11(40.7)$ & - \\
\hline & $\mathrm{No}^{*}$ & $16(59.3)$ & - \\
\hline Total & & $27(100.0)$ & - \\
\hline
\end{tabular}


Table 2. Frequency distribution of the clinical variables $(n=27)$ of the patients with stoma of a microregion of northern Minas Gerais, Brazil.

\begin{tabular}{|c|c|c|}
\hline Variables & Categories & $\mathrm{n}(\%)$ \\
\hline \multirow{8}{*}{$\begin{array}{l}\text { Disease/situation } \\
\text { leading to stoma } \\
\text { surgery }\end{array}$} & Neoplasia & $16(59,3)$ \\
\hline & Megacolon & $2(7,4)$ \\
\hline & $\begin{array}{l}\text { Absence. atresia and } \\
\text { congestive stenosis of the anus }\end{array}$ & $1(3,7)$ \\
\hline & Enterovesical fistula & $1(3,7)$ \\
\hline & Neurogenic bladder & $2(7,4)$ \\
\hline & Bowel obstruction & $2(7,4)$ \\
\hline & Volvo sigmoid & $2(7,4)$ \\
\hline & Diverticulitis & $1(3,7)$ \\
\hline \multirow{9}{*}{$\begin{array}{l}\text { Associated } \\
\text { diseases }\end{array}$} & $\mathrm{SAH}$ & $9(33,3)$ \\
\hline & Cardiopathy & $1(3,7)$ \\
\hline & DM & $1(3,7)$ \\
\hline & CKD & $1(3,7)$ \\
\hline & Anaemie & $1(3,7)$ \\
\hline & Chagas disease* & $1(3,7)$ \\
\hline & Mental diseasel* & $1(3,7)$ \\
\hline & Epilepsy & $1(3,7)$ \\
\hline & Do not have & $12(44,4)$ \\
\hline \multirow{3}{*}{ General state } & Good & $26(96,3)$ \\
\hline & Regular & $1(3,7)$ \\
\hline & Bad & $0(0)$ \\
\hline \multirow{4}{*}{ Locomotion } & Wanders & $25(92,6)$ \\
\hline & $\begin{array}{l}\text { Wandering with the aid of a } \\
\text { prosthesis/orthosis }\end{array}$ & $0(0)$ \\
\hline & Do not wander & $1(3,7)$ \\
\hline & Wheelchair & $0(0)$ \\
\hline \multirow{5}{*}{ BMl } & Low weight $(<18.5)$ & $2(7,4)$ \\
\hline & Normal $(18,5-24,9)$ & $9(33,3)$ \\
\hline & Overweight (25-29.9) & $11(40,8)$ \\
\hline & Obesity $(\geq 30)$ & $4(14,8)$ \\
\hline & $\begin{array}{l}\text { Not applicable (no BMI for } \\
\text { child }<2 \text { ) }\end{array}$ & $1(3,7)$ \\
\hline
\end{tabular}

* The patient has two associated diseases

\section{DISCUSSION}

The theme about elimination stoma has been gaining relevance due to the increasing number of surgeries that trigger its manufacture. In Brazil, this is due to the increase in non-communicable chronic diseases related to people's longer life expectancy, as well as the increase in urban violence and traffic accidents ${ }^{6}$.

The number of studies on stoma has been increasing and these seek to contribute to the improvement of the performance of professionals involved in the care and planning of health actions. They aim, above all, to direct health policies that contemplate this clientele.

The prevalence of people with stoma identified in the microregion of the study is below that established by the International Association of Ostomized (IAO) and the Brazilian Association of Ostomized (BRASO). However, this result is like that found in a study developed in other municipalities of Minas Gerais. Such situation may be related to the lack of knowledge of the users of the microregion understudy on the SAHOP, since the diagnostic evaluation of the SAHOP in Minas Gerais revealed that few people receive care by the state and municipal programs ${ }^{7}$.

The socio-demographic and economic evaluation demonstrates the predominance of people with a stoma in men, a result also described in studies developed in other Brazilian regions ${ }^{8}$. This data may be related to the greater exposure of men to trauma, diseases and injuries, as well as their lower frequency in health promotion and prevention services. Such a posture is described as a factor that makes difficult the diagnosis and the early treatment of the diseases and diseases that lead to the confection of the stoma?

Patients with stoma of this microregion are mostly retirees, pensioners, beneficiaries or work with low remuneration, constituting a clientele with low income. These results are present in a study of different regions of Brazil ${ }^{10}$. It should be noted that in the north of Minas Gerais, along with the Vale do Jequitinhonha, there are many municipalities with the highest levels of poverty in the state ${ }^{11}$.

Previous studies have shown that the level of education is associated with self-care ${ }^{6,9}$. It is worth mentioning that the level of schooling exerts influence on the individual's capacity for understanding of its health. The high illiteracy rate has an impact on patients' quality of life, their ability to seek care and guarantee their rights 5 .

In this sense, the illiteracy of a significant number of patients is a worrying factor, since the lower level of education makes access to knowledge about the disease difficult, making the patient with passive and dependent stoma feeling unable to perform the self-care and, above all, undermining its rehabilitation process. ${ }^{12,13}$.

It is understood that this ability to acquire knowledge in health motivates the individual to efficiently seek resources for self-care, maintenance, promotion and recovery of health ${ }^{14}$. Thus, it is the professional's 
responsibility to develop health literacy skills, seeking to overcome the barriers and emphasize the potential presented by the patient, offering them the conditions to achieve their autonomy.

Recognizing the importance of education is an essential step in the improvement of nursing practice and becomes an important tool in the maintenance, prevention and promotion of the health of the individual with the stoma. The problematization and the joint production of knowledge materialize as an exercise of autonomy and potentiate the care and self-care ${ }^{15}$.

Most of the participants reported discomfort and embarrassment due to unpleasant odour gases from involuntary bowel movements. These imbalances of physiological order provide psychological and spiritual changes in people with a stoma, negatively impacting their quality of life ${ }^{2}$.

Regarding the causes of indication of the stoma, the neoplasia was more prominent, with a predominance of colon and rectum tumours. In Brazil, colon and rectum cancer is one of the main surgical causes for the manufacture of stoming ${ }^{7,10,16}$. This type of cancer is related to obesity, a situation observed in this study ${ }^{17}$.

The most relevant clinical complications observed in the study were related to incorrect use of the device, such as excessive cutting of the orifice of the protective barrier, with dermatitis being the most prominent complication. Similar studies demonstrate that dermatitis is the main cutaneous complication presented by patients with stoma ${ }^{8,18}$.

Weight gain was a worrying factor observed in the study since it is related to complications such as retraction, prolapse and paraestomal hernia. Considering that a significant part of the research participants was overweight and obesity and that a paraestomal hernia was the second most common complication presented by people with a stoma, the follow-up and the professional assistance are of extreme importance for the prevention of these complications ${ }^{18,19}$.

In relation to the height of the stoma, it is worth mentioning the great number of patients who have a low stoma and at the height of the skin. This situation may lead to the difficulty of adherence to the device, which may increase the risk of detachment and occurrence of dermatitis, as evidenced in this study. In this sense, it is necessary to use a greater quantity of products and/ or convex device and/or belt, raising the cost of care to these users ${ }^{8}$.

Significant numbers of stomas were found in the upper quadrant of the abdomen, which was unusual and inadequate. Adequate stomatal location is a determining factor for hygiene and adaptation of the collector device, provides better adhesion of this device, avoiding effluent leakage with the peristomal skin, and prevents possible complications. In this sense, the demarcation of the stoma is of extreme importance for the promotion of self-care, facilitating the social reintegration of the person with the stoma ${ }^{18,20}$.

The accomplishment of the demarcation by the nurse stomatherapist in Brazil has been gaining prominence and the involvement of nurses in scientific productions has been increasing in relation to the other countries of Latin America. These studies, realized in several regions of the country, show the importance of the nurse in the practice of this procedure, contributing in a relevant way to the increase of the quality of life of the patients with a stoma. The specialized performance of this professional from the preoperative period, in addition to the right of the patient, reduces the occurrence of complications of the stoma and peristomal skin and reduces anxiety and fear of the patient, allowing a significant improvement in the rehabilitation process. This practice, which confirms the importance of differentiated knowledge of the stomatherapist in this practice and in the management of care for people with a stoma, is also shared by developed countries such as Ireland ${ }^{20-23}$.

Some patients reported that the device management procedure was guided by a nursing professional. This fact stimulates the discussion about the nursing professionals' knowledge regarding care with the patient with a stoma and the importance of the permanent education of these professionals to guarantee a safe and effective care ${ }^{24}$. A study realized in a public hospital in the country's capital suggests the implementation of the nursing process as a way of systematizing care. Through the nursing consultation, nurses evaluate their own care and improve the quality of care for patients with stoma ${ }^{25}$. Other scientific productions have also highlighted the systematization of nursing care as a facilitating instrument in the rehabilitation of the person with the stoma, to minimize suffering and stimulate self-care, guaranteeing the integrality of the care provided to these patients ${ }^{1}$. 
It should be noted that the patients were not evaluated periodically, which may have caused the clinical complications of stoma and peristomy verified in the study. It has been shown in a recent study that complications can be prevented by frequent evaluation of patients, to identify risk factors that may lead to complications ${ }^{18}$. This demonstrates the importance of patient follow-up by the nurse ${ }^{26}$. This professional can provide care and stimulate self-care. Such measures are essential for the rehabilitation of the patient with ${ }^{12,13}$.

It is worth mentioning that the study had as a limitation the difficulty of moving the patients with a stoma to the headquarters of the SAHOP in this microregion. This difficulty, evidenced mainly in rural patients, constitutes a barrier to the use of health services and may compromise the quality of care provided. This refers to a reflection on the distribution of the reference between municipalities ${ }^{8}$.

\section{CONCLUSION}

The prevalence of people with stoma identified was consistent with that found in some municipalities in Minas Gerais and is below that established by the IAO and BRASO.
Most participants had only a few years of study and a significant portion was illiterate. There was a predominance of married people, men, with low economic status, altered body mass index, in good general condition and with independence to ambulate.

A colostomy was the most frequent type of stoma. Neoplasia was the main reason for the manufacture of the stoma, with a greater emphasis on rectal neoplasia. Dermatitis was the main complication of the stoma and peristomal region and was related to incorrect use of the device. Other studies on this theme should be developed, seeking to stimulate reflections on the importance of integrated care, self-care and preventive actions and early detection of pathologies and diseases that lead to the manufacture of stomas.

\section{AUTHORS CONTRIBUTION}

Conceptualization, Barros ER and Oliveira CM; Methodology, Barros ER; Oliveira CM and Borges EL; Investigation, Barros ER and Oliveira CM; Writing First version, Barros ER and Oliveira CM; Writing Revision \& Edition, Borges EL; Supervision, Borges EL

\section{REFERENCES}

1. Jesus PBR, Sena MN, Bispo NO, Alves PS, Santos DM. Sistematização da assistência de enfermagem às pessoas com estomias intestinais: revisão integrativa. ESTIMA, Braz J Enterostomal Ther. 2018;16:e1718. https://doi.org/10.30886/ estima.v16.418 PT

2. Coelho AR, Santos FS, Poggetto MTD. A estomia mudando a vida: enfrentar para viver. REME Rev Min Enferm. 2013;17(2):258-67. https://doi.org/10.5935/14152762.20130021

3. Brasil. Ministério da Saúde. Secretaria de Atenção à Saúde. Dispõe sobre as Diretrizes Nacionais para a Atenção à Saúde das Pessoas Ostomizadas no âmbito do Sistema Único de Saúde. Portaria n. 400, 16 novembro 2009. Brasília, 2009.

4. Ferreira Junior S, Fahel MCX, Horta CJG, DinizJS. Desigualdades nas necessidades em saúde entre os municípios do estado de Minas Gerais: uma abordagem empírica no auxílio às políticas públicas. Rev Administração Pública e Gestão Social (APGS). 2017;9(2):75-134.

5. Instituto Brasileiro de Geografia e Estatística. Censo Demográfico 2010. Características da população e dos domicílios: resultados do universo [Internet]. 2010 [cited out. 2017]. Available at: https://ww2.ibge.gov.br/home/estatistica/ populacao/censo2010/caracteristicas da populacao/ tabelas pdf/tab1.pdf
6. Lenza NFB, Sonobe HM, Buetto LS, Santos MG, Lima MS. O ensino do autocuidado aos pacientes estomizados e seus familiares: uma revisão integrativa. Rev Bras Promoç Saúde. 2013;26(1):139-45. https://doi.org/10.5020/18061230.2013. p139

7. Moraes JT, Assunção RS, Sá FS, Lessa ER, Corrêa LS. Perfil de pessoas estomizadas de uma região de saúde mineira. Enferm Foco. 2016;7(2):22-26. https://doi.org/10.21675/2357707X.2016.v7.n2.788

8. Freitas JPC; Borges EL; Bodevan EC. Caracterização da clientela e avaliação de serviço de atenção à saúde da pessoa com estomia de eliminação. ESTIMA, Braz J Enterostomal Ther. 2018;16:e0918. https://doi.org/10.30886/estima.v16.402 PT

9. Miranda SM, Luz MHBA, Sonobe HM, Andrade EMLR, Moura ECC. Caracterização sociodemográfica e clínica de pessoas com estomia em Teresina. ESTIMA, Braz J Enterostomal Ther. 2016;14(1):29-35. https://doi.org/10.5327/z18063144201600010005

10. Aguiar JC, Pereira APS, Galisteu KJ, Lourenção LG, Pinto MH. Aspectos sociodemográficos e clínicos de estomizados intestinais provisórios. REME Rev Min Enferm. 2017;21:e1013. https://doi.org/10.5935/1415-2762.20170023

11. Oliveira DBO, Fernandes EA. A inter-relação entre pobreza e meio ambiente para os municípios de Minas Gerais. Rev Economia e Agronegócio (REA). 2017;15(1):1614-79. 
12. Almeida EJ, Silva AL. Caracterização do Perfil Epidemiológico dos Estomizados em Hospitais da Secretaria de Estado de Saúde do Distrito Federal. ESTIMA, Braz J Enterostomal Ther. 2015;13(1):6-11. https://doi.org/https://doi.org/10.5327/ z1806-3144201500010004

13. Luz ALA, Luz MHBA, Antunes A, Oliveira GS, Andrade EMLR, Miranda SM. Perfil de los pacientes ostomizados: revisión integrativa de la literatura. Cultura de los Cuidados. 2014;18(39):115-23. https://doi.org/10.7184/cuid.2014.39.13

14. Fung CSC, Yu EYT, Guo VY, Wong CKH, Kung K, Ho SY, et al. Development of a Health Empowerment Programme to improve the health of working poor families: protocol for a prospective cohort study in Hong Kong. BMJ Open. 2016;6(2):e010015. https://doi.org/10.1136/ bmjopen-2015-010015

15. Gazzinelli MF, Souza V, Fonseca RMGS, Fernandes MM, Carneiro ACLLC, Godinho LK. Práticas educativas grupais na atenção básica: padrões de interação entre profissionais, usuários e conhecimento. Rev Esc Enferm USP. 2017;49(2):284-91. https://doi.org/10.1590/50080623420150000200014

16. Valle TD, Turrini RNT, Poveda VB. Fatores intervenientes para o início do tratamento de pacientes com câncer de estômago e colorretal. Rev Latino-Am Enferm. 2017;25:e2879. https:// doi.org/10.1590/1518-8345.1493.2879

17. Sena JF, Medeiros LP, Melo MDM, Souza AJG, Freitas LS, Costa IKF. Perfil de estomizados com diagnóstico de neoplasias cadastrados em uma associação. Rev Enferm UFPE on line. 2017;11(Suppl 2):873-80.

18. Pinto IES, Queirós SMM, Queirós CDR, Silva CRR, Santos CSVB, Brito MAC. Fatores de risco associados ao desenvolvimento de complicações do estoma de eliminação e da pele periestomal. Rev Enf Ref. 2017;15(4):155-66. https://doi. org/10.12707/RIV17071
19. Wound, Ostomy and Continence Nurses Society (WOCN). Pediatric ostomy complications: best practice for clinicians. Mount Laurel: NJ, WOCN Society; 2016.

20. Silva JC, Borsatto AZ, Teixeira ER, Umpiérrez AF. Demarcação abdominal por enfermeira estomoterapêuta. Enfermería: Cuidados Humanizados. 2017;6(1):12. https://doi. org/10.22235/ech.v6i1.1365

21. 21. Teles AAS, Eltink CF, Martins LM, Lenza NFB, Sasaki VDM, Sonobe HM. Mudanças físicas, psicossociais e os sentimentos gerados pela estomia intestinal para o paciente: revisão integrativa. Rev Enferm UFPE on line. 2017;11(Suppl 2):1062-72.

22. Bonill-de las Nieves C, Capilla Díaz C, Celdrán-Mañas M, Morales-Asencio JM, Hernández-Zambrano SM, HuesoMontoro C. Percepção de pacientes ostomizados sobre os cuidados de saúde recebidos. Rev Latino-Am Enferm. 2017;25:e2961. https://doi.org/10.1590/1518$\underline{8345.2059 .2961}$

23. Freitas $R C L$, Resende JL, Rodrigues $P L$, Magalhães $M O$, Carmo IC, Resende MA, et al. Importância da atuação do enfermeiro na demarcação do estoma no pré-operatório mediato. Rev Eletrônica Acervo Saúde. 2018;(Suppl 11):S1567-S1573. https://doi.org/10.25248/REAS173 2018

24. Falkenberg MB, Mendes TPL, Moraes EP, Souza EM. Educação em saúde e educação na saúde: conceitos e implicações para a saúde coletiva. Ciência \& Saúde Coletiva. 2014;19(3):84752. https://doi.org/10.1590/1413-81232014193.01572013

25. Monteiro SNC, Kamada I, Silva AL, Souza TCR. Perfil de crianças e adolescentes estomizados atendidos de um hospital público do Distrito Federal. ESTIMA, Braz J Enterostomal Ther. 2017;12(3):23-32.

26. Vasconcellos FM, Xavier ZDM. O enfermeiro na assistência do cliente colostomizado baseado na teoria de Orem. Rev Recien. 2015;5(14):25. https://doi.org/10.24276/ rrecien2358-3088.2015.5.14.25-37 